\title{
Brain Drain: Comparative Study of Propulsive Factors
}

\author{
* Sumera Shabnum, PhD Scholar \\ ** Nadeem Iqbal, Assistant Professor (Corresponding Author) \\ *** Haseebullah Khan, Senior Economist
}

\begin{abstract}
Brain drain is one of the important aspects of development economics/Demographic transitions. A populous country has the potential to export human capital. There are so many determinants of Human Capital Outflow (HCO). Some like economic, social, and political drivers are already discussed in the previous studies. This study compares the impact of various classes of variables on the HCO. Furthermore, it gives recommendations for controlling HCO based on such results. Data is collected in the form of questionnaires from three rural and three urban areas of Peshawar. Random sampling is used. Probit models are used for comparing the significance of variables. The study shows that not only the classic variables, i.e. economic, social and political are important but also the newly introduced religious and environmental factors have a great impact on HCO. The forthcoming researchers can do further study by considering even more factors affecting the HCO. They can conduct studies for different areas and on different scales.
\end{abstract}

\section{Introduction}

Human Capital is one of the basic drivers in the prosperity of a nation along with capital, natural resources, and entrepreneurship (Djafar \& Hassan, 2012). This term was advised by Schultz (1961) in the 1960s as another name for human skills which could be inculcated like man-made capital to increase production. Brain drain was considered a common phenomenon in developing nations like African colonies and Caribbean islands. So many people migrated from East Germany, India, China, and the Soviet Union in the past. The literature review on the topic can be classified in the following phases:

By large, the views about brain drain were negative in the 1950s and 1960s. Skillful manpower is used to migrate from the third world countries toward the industrialized ones to provide for the excessive demand over there (Weinar, et al, 2020). However, it was an advantage though which science and technology could be promoted. According to the immigration reviews of the 1965 act in the US, there was massive migration from Europe and the United Kingdom toward the United States and Canada (Friedman, 1973). The terminology of 'Brain Drain' became popular in a paper describing the flight of human capital from Britain to the developed nations of America and Australia (MacKay, 1969).

Brain drain was also called an issue of the migration of diaspora from North to South where there were most of the developed nations were found. It was considered disastrous for the home country that is why a tax was suggested to be levied on such migrations (Bhagwati, 1979). Highly qualified manpower used to migrate leaving the less skillful behind. Brain drain is thought of as the emigration of professionals and qualified people to other countries for work (Weinar, et. al, 2020).

This concept was emerged in the 1990s due to globalization with the view that there might be benefits attached to migration (Stark and Wang, 2002). The diaspora was thought to increase assets at home over time (Borjas, et. al, 1996).

High earning expectations motivated the workers to find work in the developed nations (Solimano, 2002). He also found some other noticeable drivers for migration like war, political instability, ethnic discrimination as well as the affluence of family and friends. It was noted that such migrations affect the source countries not only economically but also socially (Giannoccolo, 2009).

\footnotetext{
* Department of Economics, University of Peshawar Email: sumerashabnum@uop.edu.pk

** Department of Economics, University of Peshawar Email: nadeemiqbal@ uop.edu.pk

*** Regional Accounts/GDP Wing, Bureau of Statistics, Planning and Development Department, Government of Khyber Pakhtunkhwa Email: haseebullah.1@gmail.com
} 
Push factors like poor salary, life security, getting infections, and pull factors of better job, high living standard, and political stability in the target countries made physicians emigrate (Muula, 2005). While more was discussed currently on the push and pull factors (Dauphinee, 2005).

Networking impacts the labor market side by side (Mundra, 2005). This impacts the type of jobs and remunerations of the diaspora (Patel and Vella, 2013). It was found that due to effective networking people can earn more. Research shows that some security applications affect the output of education adversely (Razin \& Wahba, 2015). The same was carried on further and was proved even in the case of the highly skilled workers (Akcigit et. al, 2016).

Some countries penalized the outgoing workers by giving them death punishment (Jalowiecki \& Gorzelak, 2004). Kenyans were asked to file their revenue details abroad or had to suffer serious charges. United States charges high taxes from the emigrants. In Eritrea, a human activist found that such taxes were collected as ransom (Akcigit et. al, 2016).

Brain drain was considered a double-way process earning remunerations on one hand and losing the skilled on another, so it was termed 'Brain strain' (Lowell, Findlay and Stewart, 2004). Some people suffer and others who gain (Docquier et al., 2012). It was suggested to provide a better economic environment in the home countries to control emigrations (Lowell et. al, 2004).

Some studies have shown the necessity of sending remunerations to home countries while others do not (Lowell et. al, 2004). It is also noted that the emigrants invest in their own countries from whatever they earn abroad (Baruch et. al, 2007).

According to some concepts, emigration resulted in increased skillful labor in the source countries which enhanced development (Ali et al. 2014)). Life security was a major pull factor for physicians as well as job opportunities and more amenities of life (Klein et al., 2009). It was observed that brain drain from transition economies resulted in increased output and hence earnings Leo'nLedesma et al. (2004). It was said to be the impact of induced education. Brain drain increases the economic development of the home countries and attracts people for education (Schiff, 2005).

Worse macroeconomic conditions in Pakistan have increased the brain drain and form the push factors for leaving the homeland (Ahmad et al. 2008). In the case of Indonesia and Malaysia, the unemployment factor is prominent among the push factors (DJafar \& Hassan, 2012). Push factors were found to be political and economic. The reasons for emigration were also found to be careeroriented (Jalowiecki \& Gorzelak, 2004).

This concept was aroused due to the brain drain in various directions which resulted in enhanced output and skill sharing. The literature thus formed comprises of all the relevant concepts like brain drain, brain gain and brain circulation waste' (Jalowiecki \& Gorzelak, 2004). However, brain circulation is a micro concept but human capital outflow to various places is considered based on push and pull factors at an aggregate level (Teferra, 2005).

It was found that middle-class Pakistanis mostly migrated for the sake of work and study (Bashir et al., 2013). Research showed that factors like inflation and joblessness increased brain drain while economic development increased it (Arouri et al., 2014). The income increments in the public and private sectors cannot cope with the pace of inflation in Pakistan. Whereas, in developed countries, the earnings are 30 to 40 folds due to which inflation causes brain drain to increase proportionally and positively (Ahmad et al. 2008).

It is thought that through the management of human skills mobilization, all the concerned countries will get more benefit. It is a broader and comprehensive concept as compared to all the previous concepts of brain drain already discussed. Multinational organizations have played a vital role in this direction (Stahl et al, 2012).

People from Pakistan migrate to different countries depending on the walks of life they belong to. For example, the diploma holders and skilled people mostly go to the Kingdom of Saudi Arabia (KSA); Doctors to KSA, USA and England; Engineers to KSA and UAE; teachers to UAE; English teachers and IT professionals have demand worldwide; and so on. However, there is no specific rule. From Pakistan, mostly, young males go abroad. Sometimes, they go for studies on scholarships to the USA, UK, China, Russia, etc., and sometimes for job purposes. Some such people just leave to get rid of their responsibilities and lead a liberal life elsewhere. Females also migrate for study and work purposes but their ratio is lower. Females are more often migrated along with their families as dependents. Studies show that over time, the rate of emigration has decreased due to 
development in the economic and financial sectors. Some other studies have pointed out inflation, unemployment, and increase in trade as major factors for brain drain from Pakistan.

However ample amount of work is done on brain drain but in the case of Pakistan, there is no proper research conducted on the factors other than economic, social, and political. Some studies almost equalize the significance of all such factors as in the case of Hashmi et al. (2012); whereas, the scenario is different in the research work conducted by Afridi and Baloch(2015) which creates confusion as to how much these factors contribute toward the volume of brain drain.

Here in this study, firstly, proper consideration is given to religious and environmental factors which were not touched before as major factors in academic studies carried out for Pakistan. Secondly, almost 72 sub-factors belonging to economic, social, political, religious, and environmental factor group categories are taken into account to have a clear and exhaustive analysis. Thirdly, the probit model is used for finding out the significance of each of the sub-factors belonging to these classes of factors to assess the contribution of each of them toward the brain drain.

The study aimed to find out the significant economic, social, political, religious, and environmental factors of brain drain in Pakistan.

The following hypotheses were studied through the probit model:

H1: Economic factors do not have a significant impact on brain drain from Pakistan.

$\mathrm{H} 2$ : $\quad$ Social factors do not have a significant impact on brain drain from Pakistan.

H3: Political factors do not have a significant impact on brain drain from Pakistan.

H4: Religious factors do not have a significant impact on brain drain from Pakistan.

H5: Environmental factors do not have a significant impact on brain drain from Pakistan.

The significance of the study is that it incorporates some new causes of brain drain along with the old ones and their resultant economic impact on Khyber Pakhtunkhwa (KP), Pakistan. Being a developing country, Pakistan needs smart planning to control brain drain. At first, it was thought that only economic factors were significant drivers of brain drain. This study proves the social, political, environmental, and religious factors also as significant propelling factors. It also helps in incorporating policies to limit the emigration of the cream of society and hence decrease the negative impact of brain drain.

\section{Model of the Study}

The previous studies on the subject were by large subjective except a few with some practical work. Panel data was collected by various studies conducted by Ali et al. (2014). Primary sources of data like questionnaires and interviews were carried on as pointed out by Hashmi et al. (2012) and Sajjad (2008). This study also uses the methodology of questionnaires. The former researchers have mostly avoided models except a few; for example, Afridi and Baloch (2015) and Ali et al. (2014). The model of this study is:

$$
H C O=b_{0}+b_{1} E F+b_{2} S F+b_{3} P F+b_{4} R F+b_{5} E n F+e
$$

Here $\mathrm{HCO}$ is used for brain drain, EF for economic factors, SF for social factors, PF for Political Factors, RF for religious factors, and EnF for environmental factors.

As a requirement of the model, the errors were assumed to follow a Normal distribution. The probit model is good in removing the problems of Ordinary Least Squares by fitting a nonlinear function to the data. Probit model can be generalized to account for non-constant error variances in more advanced econometric settings (known as heteroskedastic probit models) and hence are used in some contexts by economists and political scientists.

Probit model was used to estimate data as it is best suited in such circumstances where the dependent variable is dichotomous like yes/ no, like/ dislike etc. The errors in the model were supposed to have a normal distribution function which could occupy any number in the range of 0 and 1. Probit model fits a non-linear function to the data hence it is good at removing any issues concerned with the ordinary least squares. The model can also be generalized to accommodate for advanced settings of econometrics so they are used by both political science researchers and economists.

According to the study under consideration, there was only one dependent variable and many independent variables collected under a few categories. Brain drain was considered as the common dependent variable for all the hypotheses formed to see which class of factors had the most impact on brain drain and whether the economic, social, and political variables stood out to be the most important or the religious and environmental factors. Brain drain was a binary variable due to the 
possibility of just two possible outcomes; other variables had Likert Scale to accommodate for the degree of acceptance.

The sub-models formed were:

$$
\begin{aligned}
& \mathrm{HCO}=\mathrm{f} \text { (Economic Factors) } \\
& \mathrm{HCO}=\mathrm{f} \text { (Social Factors) } \\
& \mathrm{HCO}=\mathrm{f} \text { (Political Factors) } \\
& \mathrm{HCO}=\mathrm{f} \text { (Religious Factors) } \\
& \mathrm{HCO}=\mathrm{f} \text { (Environmental Factors) }
\end{aligned}
$$

Almost all the independent variables taken were from a pull factors point of view.

\section{Data Source}

Data source was primary in the form of questionnaires which were filled out by the respective households of the inhabitants who were emigrated. Peshawar is a representative city of Khyber Pakhtunkhwa Province in Pakistan was taken as the universe of the study. As a sample, three areas each from rural and urban areas of Peshawar were chosen for primary data collection. Rural areas were: Pakeha Ghulam, Spena Warhe, Achini; and urban areas were: Gulbahar, Gulberg, and Hayatabad.

\section{Results and Findings}

The results and findings of probit model application on the data are given below under various sub-

\begin{tabular}{|c|c|c|c|c|}
\hline \multicolumn{5}{|c|}{$\begin{aligned} \text { Marginal effects after probit } \\
y=\operatorname{Pr}(\text { HCOB) (predict) } \\
=.99627362\end{aligned}$} \\
\hline variable & $d y / d x$ & std. Err. & $\mathbf{z}$ & $P>|z|$ \\
\hline $\begin{array}{r}\text { EO } \\
\text { JAQ } \\
\text { RHW } \\
\text { LCL } \\
\text { HLS } \\
\text { CS } \\
\text { LSRI } \\
\text { TFZ } \\
\text { MBMW }\end{array}$ & $\begin{array}{l}.0030166 \\
.0032799 \\
.0038716 \\
.0078189 \\
.0059133 \\
.0067137 \\
.0033873 \\
.0010305 \\
.0030678\end{array}$ & $\begin{array}{l}.00148 \\
.00165 \\
.00194 \\
.00376 \\
.00272 \\
.00318 \\
.00158 \\
.00088 \\
.0017\end{array}$ & $\begin{array}{l}2.04 \\
1.98 \\
1.99 \\
2.08 \\
2.17 \\
2.11 \\
2.15 \\
1.17 \\
1.80\end{array}$ & $\begin{array}{l}0.041 \\
0.047 \\
0.047 \\
0.037 \\
0.030 \\
0.035 \\
0.032 \\
0.242 \\
0.072\end{array}$ \\
\hline
\end{tabular}
headings where HCO in these models denotes 'Brain Drain'.

Impact of Economic Factors

Here is the table showing the marginal effects of such drivers on $\mathrm{HCO}$ at a $95 \%$ significance level:

Table 1Economic Factors

$\mathrm{EO}=$ Economic Opportunities; JAQ= Job According to Qualification; RHW= Reward for Hard Work; LCL=Low Cost of Living; HLS= Higher Living Standard; CS= Currency Stability; LSRI= Lower and Stable Inflation Rate; TFZ= Tax-Free Zone; MBMW= Making Black-Money White.

The marginal effects of all variables in this table are low but positive which shows a direct one-to-one impact of the independent variables on the dependent HCO. Seven out of nine economic factors taken into consideration turned out to be significant at a 95\% confidence level. Past researches have also put most emphasis on the economic factors; like Sajjad (2008) and Hashmi et al. (2012) had strived to find out the degree of significance of economic, social, and political factors for brain drain and they found that all of them affect the dependent variable almost equally. However, they investigated in Lahore; while, this study was about Khyber Pakhtunkhwa (KP).

\section{Impact of Social Factors}

The table for marginal effects of social factors is given below:

\section{Table 2Social Factors}




\begin{tabular}{|r|rrrr|}
\hline $\begin{array}{r}\text { Marginal } \\
y \\
= \\
= \\
=\end{array} \begin{array}{l}\text { Pr(HCOB) (predict) } \\
.97523819\end{array}$ & & \\
\hline variable & $\mathrm{dy} / \mathrm{dx}$ & Std. Err. & $\mathrm{z}$ & $\mathrm{P}>|\mathrm{z}|$ \\
\hline BHF & .0100953 & .00394 & 2.56 & 0.010 \\
FP & .0015956 & .00285 & 0.56 & 0.576 \\
SS & .0048912 & .00362 & 1.35 & 0.177 \\
ER & .00875 & .00404 & 2.17 & 0.030 \\
CE & .0370177 & .00742 & 4.99 & 0.000 \\
SPS & .0078074 & .00316 & 2.47 & 0.013 \\
PD & .0145814 & .00408 & 3.58 & 0.000 \\
\hline
\end{tabular}

BHF= Better Health Facilities; FP= Family Pressure; SS= Social Security; ER= Equal Rights; $\mathrm{CE}=$ Children's Education; SPS $=$ Siblings and Parents Support; $\mathrm{PD}=$ Personal Development and exposure.

Here in this table, all the marginal effects are positive. Per unit change in $\mathrm{HCO}$ is higher for better health facilities, children's education, and personal development with highest for children education. The probabilities for most of them are less than 0.05 except for family pressure; and social security. The significance of social factors is also strengthened through past researches. Here again, the example of the studies by Sajjad (2008) and Hashmi et al. (2012) can be given. However, Sajjad (2008) had not decomposed the social factors into its sub-factors and Hashmi et al. (2012) had conducted the study in Lahore. However, this study has an edge over the others in that it is more detailed; there are sub-factors for each category as well as the sample is 960 , far more than the previous studies.

\section{Impact of Political Factors}

Below is the table for marginal effects of political factors on brain drain:

Table 3 Political Factors

\begin{tabular}{|c|c|c|c|c|}
\hline \multicolumn{5}{|c|}{$\begin{aligned} \text { Marginal effects after probit } \\
\begin{aligned} y & =\operatorname{Pr}(\mathrm{HCOB}) \text { (predict) } \\
& =.99056318\end{aligned}\end{aligned}$} \\
\hline variable & $d y / d x$ & std. Err. & $\mathbf{z}$ & $P>|z|$ \\
\hline $\begin{array}{r}\text { SG } \\
\text { LS } \\
\text { HB } \\
\text { RL } \\
\text { LE } \\
\text { GRCT } \\
\text { GRPC }\end{array}$ & $\begin{array}{l}.0056565 \\
.0151929 \\
.0205558 \\
.0035802 \\
.0072601 \\
.0028895 \\
.0010983\end{array}$ & $\begin{array}{l}.00286 \\
.00561 \\
.00769 \\
.00228 \\
.00285 \\
.00252 \\
.00212\end{array}$ & $\begin{array}{l}1.98 \\
2.71 \\
2.67 \\
1.57 \\
2.55 \\
1.15 \\
0.52\end{array}$ & $\begin{array}{l}0.048 \\
0.007 \\
0.008 \\
0.117 \\
0.011 \\
0.252 \\
0.605\end{array}$ \\
\hline
\end{tabular}

$\mathrm{SG}=$ Stable Government; LS= Life Security; RL= Rule of Law; HB= Honest Bureaucracy; LE $=$ Liberty of Expression; GRCT $=$ Getting Rid of Court Trial; GRPC $=$ Getting Rid of Punishment for Crime.

Political factors are influential activities related to government policy. From table 3, marginal effects of honest bureaucracy and life Security are higher than others being, however, all are positive. Looking at the $\mathrm{z}$ values and probabilities, stable government, life security, honest bureaucracy, and liberty of expression are significant at a 95\% confidence level.

\section{Impact of Religious Factors}

Religious factors were the neglected ones in almost all the academic studies; however, the multinationals used to consider even these factors in their market research projects. Following is the table for marginal effects of religious factors on brain drain.

\section{Table 4 Religious Factors}

\begin{tabular}{|c|c|c|c|c|}
\hline \multicolumn{5}{|c|}{$\begin{array}{r}\text { Marginal effects after probit } \\
y=\operatorname{Pr}(\mathrm{HCOB}) \text { (predict) } \\
=\quad .8864029\end{array}$} \\
\hline variable & $d y / d x$ & Std. Err. & z & $P>|z|$ \\
\hline $\begin{array}{r}\text { MI } \\
P \\
\text { RC }\end{array}$ & $\begin{array}{l}.0230407 \\
.0272233 \\
.0196735\end{array}$ & $\begin{array}{l}.00919 \\
.00709 \\
.00738\end{array}$ & $\begin{array}{l}2.51 \\
3.84 \\
2.66\end{array}$ & $\begin{array}{l}0.012 \\
0.000 \\
0.008\end{array}$ \\
\hline
\end{tabular}


MI= Minority Issues; $\mathrm{P}=$ Preaching; $\mathrm{RC}=$ Religious Conformity

This shows that all the religious factors taken into account stood significant, among which preaching is on the top.

\section{Impact of Environmental Factors}

Environmental factors are almost new to academic researches. By observing their impact on the people, they were included in the questionnaire to find out and compare their real impact on brain drain.

\section{Table 5 Environmental Factors}

\begin{tabular}{|c|c|c|c|c|}
\hline \multicolumn{5}{|c|}{$\begin{aligned} \text { Marginal effects after probit } \\
y=\operatorname{Pr}(\mathrm{HCOB}) \text { (predict) } \\
=.92183675\end{aligned}$} \\
\hline variable & $\mathrm{dy} / \mathrm{dx}$ & Std. Err. & $z$ & $P>|z|$ \\
\hline $\begin{array}{l}\text { W } \\
\text { GF } \\
\text { HP } \\
\text { SR } \\
\text { AR } \\
\text { NF }\end{array}$ & $\begin{array}{l}.0248299 \\
.0139788 \\
.0153374 \\
.0171244 \\
.0243074 \\
.0230922\end{array}$ & $\begin{array}{l}.00804 \\
.00792 \\
.00679 \\
.00766 \\
.00821 \\
.00699\end{array}$ & $\begin{array}{l}3.09 \\
1.76 \\
2.26 \\
2.23 \\
2.96 \\
3.30\end{array}$ & $\begin{array}{l}0.002 \\
0.078 \\
0.024 \\
0.025 \\
0.003 \\
0.001\end{array}$ \\
\hline
\end{tabular}

$\mathrm{NF}=$ Nutritious Food; W= Weather; GF= Geographical Features; HP= Historical Places; SR= Spiritual Reasons; AR= Astrological Reasons.

All the marginal effects are positive which shows a direct one-to-one relationship between the regressors and the regressand. Among probabilities, all are below 0.05 except for GF (geographical features) which has a probability of 0.078 .

From the study as a whole, it turned out that all types of factors have a great significance and value for brain drain; whether they are economic, social, political, religious, or environmental. From the collected data and analysis, religious factors have shown up to be the most significant of all. Other types of factors also comprised of most of the significant sub-factors.

\section{Conclusion}

The research is important as it has opened some new avenues for consideration. Researchers have more choice of factors to be considered beyond the routine economic, social, and political causes. Even some of the new factors proved to be vital. For decades, the subjective approach adopted for the very important research of the drivers of brain drain was practicality at its minimum if somewhere found. In this study, the effort was made to break the barrier and collect data from the very concerned people for getting an unbiased result.

It will go a very long way to guide the new researchers on how to conduct their study on such topics. They can have it for some other related areas of interest and importance too. The government can take help of it in formulating policies as the recommendations are given purely on the need basis ascertained from the results of the study as to where there are gaps and pitfalls that Pakistan is losing its cream diaspora.

Economic policies can be formed by keeping in view the resultant significant and insignificant factors of brain drain. According to the results of this study, the prime needs are the creation of employment opportunities, paying a reward for hard work, provide low-cost better living standard, stabilization of currency, controlled inflation, better health facilities, equal rights to all irrespective of social status, religion, language and ethnicity, free of cost elementary education and quality higher education, government support to the dependents, climate for personal development and exposure, political stability, ensuring life security, rule of law, liberty of expression, solution to minority issues, cheap \& healthy food.

\section{References}

Afridi, F., K., Baloch, Q., B., (2015). Preventing and reversing Pakistan's brain drain: an empirical analysis of public sector universities of Khyber Pakhtunkhwa. Abasyn Journal of Social Sciences: 8(2), 363-379.

Ahmad, N., Hussain, Z., Sial, M. H., Hussain, I., \& Akram, W. (2008). Macroeconomic determinants of international migration from Pakistan. Pakistan Economic and Social Review, 46, 85-99. 
Akcigit, U., Baslandze, S., \& Stantcheva, S. (2016). Taxation and the international mobility of inventors. American Economic Review, American Economic Association: 106(10), 29302981.

Ali, A., Mujahid, N., Rashid, Y., Shahbaz, M., (2014). HCO and economic misery: Fresh evidence for Pakistan. Social Indicators Research: 119(3).

Arouri, M., Rashid, Y., Shahbaz, M., \& Teulon, F. (2014). Short and long-run determinants of brain drain: Evidence from Pakistan (No. 2014-113).

Baruch, Y., Pawan S. Budhwar, Khatri, N. (2007).Brain drain: Inclination to stay abroad after studies. Journal of World Business: 42(1), 99-112.

Bashir, M. F., Xu, C., Zaman, K., \& Akhmat, G. (2013).Key factors determining the rationale for brain drain: An irony never recovered. International Journal of Economics and Empirical Research: 2(8), 308-320.

Bhagwati, J. N. (1979). International migration of the highly skilled: economics, ethics and taxes. Third world quarterly, 1(3), 17-30.

Borjas, G. J., \& Bratsberg, B. (1996). Who leaves the outmigration of the foreign-born? Review of Economics and Statistics: 78(1), 165-176.

Dauphinee (2005). Physician migration to and from Canada: The challenge of finding the ethical and political balance between the individual's right to mobility and recruitment to underserved communities. Journal of Continuing Education in the Health Professions: 25(1), 22-29.

Djafar, F., \& Hassan, M. K. H. (2012). Dynamics of push and pull factors of migrant workers in developing countries: The case of Indonesian workers in Malaysia. Dynamics: 4(12), 703711.

Docquier, F., Rapoport, H., Salomone, S. (2012). Remittances, migrants' education and immigration policy: Theory and evidence from bilateral data" Regional Science and Urban Economics: 42(5), 817-828.

Friedman, S., (1973). The effect of the US Immigration Act of 1965 on the flow of skilled migrants from less developed countries. World Development: 1(8), 39-44.

Giannoccolo, P. (2009). The brain drain: a survey of the literature. Università degli Studi di MilanoBicocca, Department of Statistics, Working Paper, (2006-03), 02.

Hashmi, M. A., Zeeshan, A., Mehmood, T., Naqvi, S. A. H., Sheikh, F. M. (2012). Factors driving brain drain in Pakistan: An exploratory view. Journal of Asian Business Strategy: 2(2), 7-20.

Jalowiecki, B. and Gorzelak, G. J. (2004).Brain drain, brain gain, and mobility: Theories and prospective methods. Higher Education in Europe: 29 (3), 299-308.

Klein, D., Ho Fmeister, M., Lockyer, J., Crutcher, R., \& Fidler, H. (2009). Push and pull and plant: The personal side of physician immigration to Alberta. Family Medicine 41(3):197-201.

Leo'n-Ledesma, M., \& Piracha, M. (2004). International migration and the role of remittances in Eastern Europe. International Migra: 42(4), 65-83.

Lowell, B L, Findlay, A. and Stewart, E. (2004). Brain Strain: Optimising Highly Skilled Migration from Developing Countries. Asylum and Migration Working Paper 3.

MacKay DI. (1969). Geographical mobility and the brain drain: A case study of Aberdeen University graduates, 1860-1960. George Allen and Unwin.

Mundra, K. (2005). Immigration and international trade: A semi-parametric empirical investigation. The Journal of International Trade \& Economic Development: 14(1), 65-91.

Muula, A.S. (2005). Is there a solution to the brain drain of health professionals and knowledge from Africa? Croatian Medical Journal: 46, 21-29.

Patel, K., Vella, F. (2013). Immigration networks and their implications for occupational choice and wages. Review of Economics and Statistics: 95(4), 1249-1277.

Razin, A., Wahba, J. (2015). Welfare magnet hypothesis, fiscal burden, and immigration skill selectivity. The Scandinavian Journal of Economics: 117(2), 369-402.

Sajjad, N. (2008). Causes and solutions to intellectual brain drain In Pakistan" The Dialogue 4(1), 3154.

Schiff, M., (2005). Brain gain: Claims about its size and impact on welfare and growth are greatly exaggerated. IZA DP No. 1599.

Schultz, T. W. (1961). Investment in human capital. The American economic review, 51(1), 1-17. 
Solimano, A. (2002). Globalizing talent and human capital: Implications for developing countries. ABCDE Conference Europe, Oslo.

Stahl, G., et al. (2012). Leveraging your talent: Six principles of effective global talent management. MIT Sloan Management Review, 53: 25-42.

Stark, O. \& Wang Y. (2002). Inducing human capital formation: Migration as a substitute for subsidies. Journal of Public Economics: 86(1), 29-46.

Teferra, D. (2005). Brain circulation: Unparalleled opportunities, underlying challenges, and outmoded presumptions. Journal of Studies in International Education: 9(3).

Weinar, A., \& Klekowski von Koppenfels, A. (2020). Highly-skilled migration: between settlement and mobility: IMISCOE short reader (p. 108). Springer Nature. 